\title{
Biopotentials of secondary metabolites isolated from marine sponges
}

\author{
Joseph Selvin' ${ }^{1} \&$ A. P. Lipton ${ }^{2}$ \\ ${ }^{1}$ Department of Biotechnology, Malankara Catholic College, Mariagiri, Kaliakavilai-629153, \\ Kanyakumari District, India \\ E-mail: selvinj@rediffmail.com \\ ${ }^{2}$ Marine Biotechnology Laboratory, Central Marine Fisheries Research Institute, Vizhinjam - 695 521, \\ Thiruvananthapuram, India
}

Received 13 February 2003 ; in revised form 4 July 2003 ; accepted 29 July 2003

Key words: sponge, secondary-metabolites, Dendrilla nigra, Axinella donnani, Clathria gorgonoides, antibacterial, brineshrimp-cytotoxicity, larvicidal, antifouling, ichthyotoxic

\begin{abstract}
The secondary metabolites of three sponges collected as bycatch in the fishing nets were explored for biological potencies. The sponge Dendrilla nigra exhibited wider biological activity. It showed potent activity in antibacterial, brineshrimp cytotoxicity, larvicidal, antifouling and ichthyotoxic assays. One of the well-studied cytotoxic sponge Axinella donnani was least active in brineshrimp cytotoxicity assay. The secondary metabolites of Clathria gorgonoides were highly cytotoxic albeit it showed least activity in other bioassays. Based on the present findings, it could be inferred that the bioassay-guided fractionation and purification of D. nigra may come up with potent bioactive drugs.
\end{abstract}

\section{Introduction}

Marine Secondary Metabolites (MSMs) are organic compounds produced by microbes, sponges, seaweeds and other marine organisms (Attaway \& Zaborsky, 1993). The host organism biosynthesizes these compounds as non-primary or secondary metabolites to protect themselves and to maintain homeostasis in their environment (Selvin, 2002). Some of these secondary metabolites offer avenues for developing potent drugs. The rapid growth in the chemistry of marine organisms over the last 15 years has led to the discovery of a large number of new structures, many of which have no precedence among structures of terrestrial origin and possess previously unknown pharmacological and toxicological properties.

Retrospective of research in this field indicated that although a number of diverse biologically active compounds have been isolated from marine organisms, the number of compounds taken-up for the field trial/clinical use is scanty. This may be due to the failure of successful collection of concerned source organism in bulk or which have same sort of sec- ondary metabolites. Therefore exploration of chemical ecology of secondary metabolites synthesis and development of drugs from sponge-associated microorganisms are becoming a promising venture (Soniya, 2003). Although chemical synthesis of bioactive secondary metabolites have been developed, the availability of source organism in bulk is inevitable for systemic drug development. Successful development of drugs from the sea is completely relying on the availability of source organism or the organism having same secondary metabolites. Therefore the knowledge of habitat, areas of abundance, seasonality and ecofriendly bulk collection of the source organism are very important for the successful development of potent bioactive drugs. In this context, the present study was initiated to find out the biopotentials of marine sponges collected as bycatch in fishing nets.

\section{Materials and methods}

An eco-friendly bulk collection of sponges as bycatch in the fishing nets was carried out at Kanyakumari 
coast (southeast coast of India). Three species of sponges were collected, identified and taken-up for isolation and bioactivity screening of secondary metabolites. During November to December and April to August of every year, the rough sea weather was prevailed in the Kanyakumari coast led dislodging of diverse sponges, gorgonids, soft corals and ascidians, which were caught in the fishing nets. These bycatches were segregated and collected freshly from the nets and washed in fresh seawater to remove dirt and symbionts and drained off the excess water on a blotting sheet. After recording their colour pattern for identification, the sponge pieces were separately preserved in methanol. For the isolation of secondary metabolites, they were minced in a tissue homogenizer (Omni, U.S.A.) and extracted with methanol and methanol-dichloromethane (1:1). The combined extract was filtered and concentrated in a rotary vacuum evaporator (Buchi) at room temperature.

\section{Bioassays}

Antibacterial activity of MSMs was studied using seven species of bacterial type cultures (MTCC) and four species of shrimp/fish pathogenic bacteria (obtained from Marine Biotechnology lab, Vizhinjam) as test organisms. The modified cylinder plate double layer method was used for the screening of potent antibacterial MSMs and minimum inhibitory concentration (MIC) values. In this method, the base layer was prepared with $10 \mathrm{ml}$ of $1.5 \%$ agar. Six numbers of sterile porcelain beads of $7 \mathrm{~mm}$ diameter was placed on the base layer. The overlaid seed layer was prepared by pouring $15 \mathrm{ml}$ of hot nutrient agar containing $0.2 \mathrm{ml}$ of prepared inoculum (USP, 1995; The Himedia manual, 1998). After the seed layer solidified, the porcelain beads were removed carefully with a sterile forceps. The consequent wells were filled with the appropriate test compound and control. After $18 \mathrm{~h}$ of incubation at $37 \pm 2{ }^{\circ} \mathrm{C}$, the area of inhibition zone was measured. A parallel experiment was conducted at $20 \pm 2{ }^{\circ} \mathrm{C}$ to find out the influence of temperature on the antibacterial potential of MSMs.

Brineshrimp cytotoxicity of MSMs was evaluated after Hong et al. (1998). Based on the percent mortality, the LC50 values of the test compound were determined by probit analysis (Wardlaw, 1985). The susceptibility or resistance of the mosquito larvae (Culex sp.) to the selected concentration of the extracts (larvicidal effect) was studied by adopting standard bioassay protocol (WHO, 1981). Fingerlings (1.5-2.0 $\mathrm{cm}$ ) of marine acclimated Oreochromis mossambicus were used for evaluating the ichthyotoxic potential. Immediate reflex changes and mortality of fingerlings treated with various concentrations of MSMs were observed continuously for $6 \mathrm{~h}$ and at $1 \mathrm{~h}$ interval for the next $12 \mathrm{~h}$. The acute toxicological reflexes were observed after Indap \& Pathare (1998). The newly developed 'foot adherence bioassay' was used for the evaluation of antifouling activity of MSMs (Selvin \& Lipton, 2002).

\section{Results and discussion}

\section{Collection of the source organisms}

In the present study, the Kanyakumari coast was found to be an excellent area for the collection of diverse marine sponges as bycatch in fishing nets. The landing status of sponges in this coast is more or less same, during the seasons (Lipton et al., 2003). However, the trend of frequency and quantity of landings varied according to the fishing area and nets used. The major landing species were Dendrilla nigra, Clathria gorgonoides and Axinella donnani. All these bycatch collections contained potent biologically active secondary metabolites. The recovery of extract was dependent on colour pattern and softness of the sponge body. The yield was very high in the case of $A$. donnani $(8 \mathrm{~g} / \mathrm{kg})$ followed by D. nigra $(6.0 \mathrm{~g} / \mathrm{kg})$ and C. gorgonoides $(3.8 \mathrm{~g} / \mathrm{kg})$. Literature indicated that utilization of such bycatches for bioactivity screening and or chemical elucidation was scanty. However, Ovenden \& Capon (1999) utilized a Sigmosceptrella sp. obtained from trawling operation in the Great Australian Bight for the chemical elucidation and bioactivity screening. A specimen of Dendrilla cactos collected during trawling operations in Bass strait, Australia had yielded two new alkaloids, lamellarino lamellarin-p, which was previously reported from tunicates and molluses (Urban et al., 1994).

\section{Antibacterial activity}

The secondary metabolites of sponges exhibited significant bactericidal activity. The sponge $D$. nigra exhibited broad-spectrum antibacterial activity and it inhibited the growth of all the tested bacteria (Table 1). However, A. donnani was a narrow spectrum antibacterial agent as it inhibited the growth of all the gram positive bacteria while it showed least activity to the extent of $25.0 \%$ against gram negative bacteria. 
Table 1. Antibiogram of MSMs

\begin{tabular}{|c|c|c|c|c|c|}
\hline \multirow{3}{*}{$\begin{array}{l}\text { Source organism of } \\
\text { MSMs }\end{array}$} & \multicolumn{5}{|c|}{$\%$ antibacterial activity } \\
\hline & Total $(\%)$ & \multicolumn{2}{|c|}{ Gram positive $(\%)$} & \multicolumn{2}{|c|}{ Gram negative (\%) } \\
\hline & $\overline{37^{\circ} \mathrm{C} 20^{\circ} \mathrm{C}}$ & $37^{\circ} \mathrm{C}$ & $20^{\circ} \mathrm{C}$ & $37^{\circ} \mathrm{C}$ & $20^{\circ} \mathrm{C}$ \\
\hline Dendrilla nigra & 100 & 100 & 100 & 100 & 100 \\
\hline Axinella donnani & $45.45 \quad 45.45$ & 100 & 100 & 25 & 25 \\
\hline Clathria gornonoides & $27.27 \quad 18.18$ & 66.66 & 66.66 & 12.5 & 0 \\
\hline
\end{tabular}

Most of the available reports on antibacterial property of sponges revealed their activity on gram positive bacteria. Samples of 28 demosponges collected along French coast indicated high antibacterial activity against gram positive bacteria (77\%) than gram negative bacteria (53\%) (Amade et al., 1987). As $C$. gorgonoides contained least active secondary metabolite, it inhibited only $27.27 \%$ of the tested bacteria. The activity was very much reduced against gram-negative bacteria at $37^{\circ} \mathrm{C}$ while it exhibited no activity at $20^{\circ} \mathrm{C}$.

Based on the activity range, the inhibitory potential was graded as highly active $\left(>100 \mathrm{~mm}^{2}\right)$, nearly active $\left(60-100 \mathrm{~mm}^{2}\right)$, moderately active $\left(30\right.$ to $\left.<60 \mathrm{~mm}^{2}\right)$ less active $\left(1\right.$ to $\left.<30 \mathrm{~mm}^{2}\right)$ and resistant $\left(<1 \mathrm{~mm}^{2}\right)$. The bactericidal potential of $D$. nigra was very high against Micrococcus luteus to the extent of 132.66 $\mathrm{mm}^{2}$ and $283.3 \mathrm{~mm}^{2}$ at 37 and $20^{\circ} \mathrm{C}$ respectively (Fig. 1). The high activity range was extended against one of the shrimp pathogen Vibrio fischeri with $104.62 \mathrm{~mm}^{2}$ at $20^{\circ} \mathrm{C}$ whereas the activity was very low at $37^{\circ} \mathrm{C}$. The antibacterial potential of $D$. nigra was also evidenced in 'in captivity' control of bacterial diseases of shrimp (Selvin, 2002). The nearly active range was observed against Bacillus cereus $\left(78.8 \mathrm{~mm}^{2}\right)$ at $20^{\circ} \mathrm{C}$ and Pseudomonas aeruginosa $\left(63.58 \mathrm{~mm}^{2}\right)$ at both temperatures. Five bacterial strains were nearly sensitive to $D$. nigra at different temperatures. The activity range of $B$. cereaus and Escherichia coli accounted for 50.24 and $38.46 \mathrm{~mm}^{2}$ zone, respectively, at $37^{\circ} \mathrm{C}$. One of the common shrimp pathogen $V$. alginolyticus (QS7) was moderately sensitive at $20^{\circ} \mathrm{C}$ whereas luminescent $V$. harveyi (RJM5) was less sensitive in both temperatures. In the case of $B$. subtilis, it was moderately sensitive at both temperatures. The inhibitory potential was least against $A$. hydrophila and clown fish isolates ( $\mathrm{CF} 1$ and $\mathrm{CF} 2$ ) at both temperatures.

In the case of $A$. donnani, peak bactericidal activity was noted against $A$. hydrophilla at $20^{\circ} \mathrm{C}$ to the extent of $132.66 \mathrm{~mm}^{2}$ (Fig. 2). However, at $37^{\circ} \mathrm{C}$, it was resistant. The antibacterial activity of $A$. donnani indicated its narrow spectrum as it inhibited the growth of all the three gram positive strains. The nearly active bactericidal range was observed against B. cereaus $\left(63.58 \mathrm{~mm}^{2}\right)$ and $P$. aeruginosa $\left(78.5 \mathrm{~mm}^{2}\right)$ at $20^{\circ} \mathrm{C}$. The activity range was reduced to moderate against $B$. subtilis at both temperatures, and $M$. luteus at $20^{\circ} \mathrm{C}$, however it was less active at $37^{\circ} \mathrm{C}$. The bacterial strains such as $E$. coli, V. fischeri, shrimp isolates and fish isolates produced resistant colonies against $A$. donnani at both the temperatures except CF1, which showed very least sensitivity $\left(3.14 \mathrm{~mm}^{2}\right)$ at $37^{\circ} \mathrm{C}$.

The secondary metabolite of $C$. gorgonoides was one of the least active antibacterial agents, which inhibited the growth of 27.27 and $18.18 \%$ of total bacterial species tested at $37^{\circ} \mathrm{C}$ and $20^{\circ} \mathrm{C}$, respectively (Table 1 ). The activity spectrum was narrowed towards gram negative bacteria, which inhibited the growth of $66.66 \%$, while it was not active against gram positive bacteria at $20^{\circ} \mathrm{C}$. It showed moderate activity to the extent of $63.58 \mathrm{~mm}^{2}$ inhibition area at $20^{\circ} \mathrm{C}$, with least activity at $37^{\circ} \mathrm{C}$ (Fig. 3). It was moderately bacteriostatic against $B$. cereus at both temperatures and $P$. aeruginosa at $37^{\circ} \mathrm{C}$. One gram positive and 7 gram negative species were totally resistant against $C$. gorgonoides extract.

The present findings indicated that temperature had significant influence on the antibacterial potential of MSMs. In certain cases, the activity was comparatively high in $20^{\circ} \mathrm{C}$. It may be due to the slow growth rate of bacteria at low temperatures. The MIC value of highly active MSMs indicated that $D$. nigra was a potent antibacterial compound $(\mathrm{MIC}=9.0 \mathrm{mg} / \mathrm{ml})$ followed by $A$. donnani $(\mathrm{MIC}=12.0 \mathrm{mg} / \mathrm{ml}$ ) and C. gorgonoides $(14.0 \mathrm{mg} / \mathrm{ml})$. Literature indicated that sponges contained potent antibacterial secondary metabolites. The dichloromethane-methanol (1:1) extract of the sponge Phycopsis sp. collected from the Tuticorin coast of India, exhibited antibacterial activity (Venkateswarlu \& Biabani, 1995). The bromopyrrole alkaloids found in Agelas dispar showed moderate antibiotic activity against gram positive bacteria such as $B$. Subtilis and $S$. aureaus (Caiferi et al., 1998). The latrunculid marine sponges Latrunculia sp. and Negombata sp. were contained potent antibacterial discorhabdin $\mathrm{R}$, which was chemically characterized as pyrrolaiminoquinone (Ford \& Capon, 2000). Extracts made from Sigmosceptrella sp. collected as bycatch during trawling operation in the Great Australian Bight was inhibitory against $M$. luteus, Serratia marcescens and Staphylococcus aureus (Ovenden \& Capon, 1999). Based on the present findings, it could be inferred that the bycatch collections would form an 


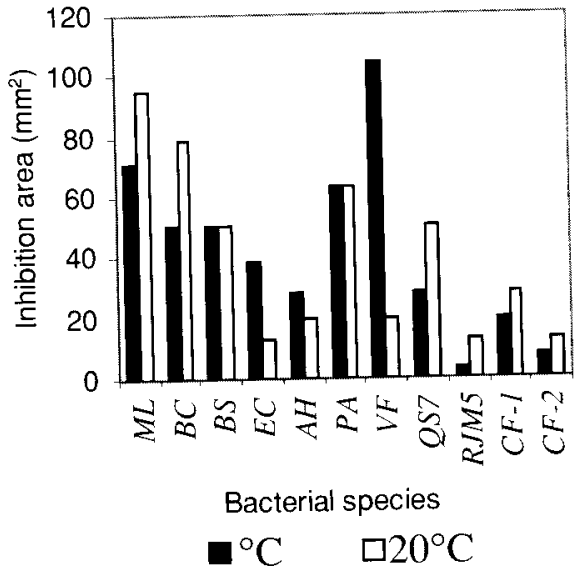

Figure 1. Antibacterial activity of Dendrilla nigra.

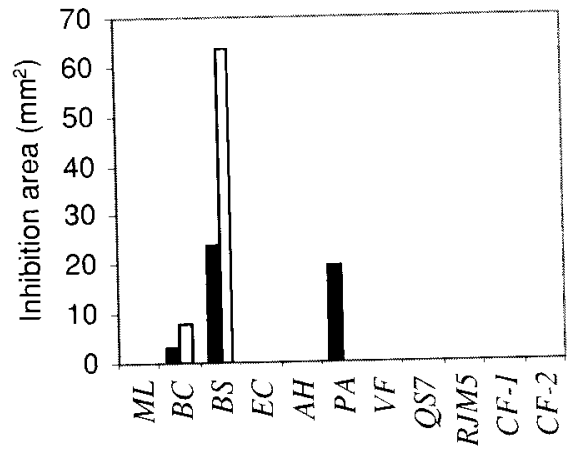

Bacterial species

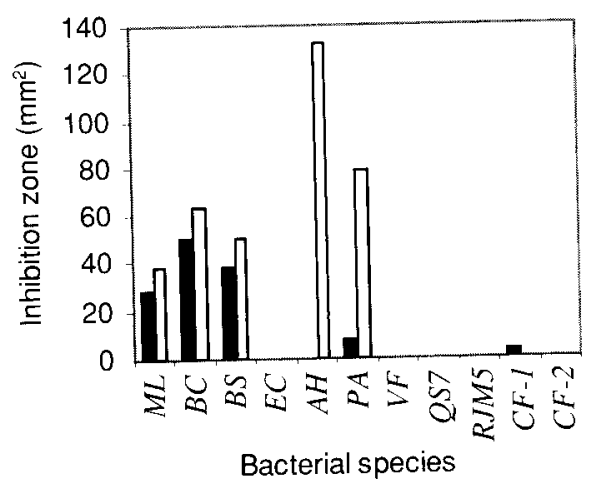

Figure 2. Antibacterial activity of Axinella donnani.

\author{
$M L-$ Micrococcus luteus \\ $B C-$ Bacillus cereus \\ $B S-$ Bacillus subtilis \\ EC-Escherichia coli \\ AH - Aeromonas hydrophila \\ $P A-P$ seudomonas aeruginosa \\ $V F$ - Vibrio fischeri \\ QS7 - Vibrio alginolyticus \\ RJM5 - Vibrio harveyi \\ CF-1-Aeromonas sp. \\ CF-2 - Aeromonas sp.
}

${ }^{\circ} \mathrm{C} \quad \square 20^{\circ} \mathrm{C}$

Figure 3. Antibacterial activity of Clathria gorgonoides.

additional resource for developing potent antibacterial agents.

\section{Brineshrimp cytotoxicity}

Results of brineshrimp cytotoxicity bioassay are presented in Table 2. The secondary metabolites of the sponge $C$. gorgonoides exhibited high toxicity against Artemia nauplii. One of the well-studied cytotoxic sponge $A$. donnani reported with vast potential of antitumour activity (Bai et al., 1991; Rudi et al., 1997) was found to be least active in the present study. Probit analysis indicated that it was least toxic and it produced $50 \%$ mortality at $5.5 \%$ level. This lesser toxicity may be due to the geographical location or habitat of the sponges. The LC50 values of C. gorgonoides and D. nigra were accounted for $0.20 \%$ and $0.28 \%$, respectively. Temperature had significantly influenced the toxicity of MSMs. The toxicity profile of MSMs considerably decreased at $20 \pm 2{ }^{\circ} \mathrm{C}$ (Table 2). At this temperature, the toxicity of $D$. nigra was reduced to no mortality at $0.4 \%$ level while the same concentration resulted in $90 \%$ mortality at $37 \pm 2{ }^{\circ} \mathrm{C}$. Similarly A. donnani showed $80 \%$ mortality at $10 \%$ level and it produced $80 \%$ mortality at $37 \pm 2{ }^{\circ} \mathrm{C}$. The same trend was noticed for $C$. gorgonoides also.

Methanol soluble extract of the Korean sponge Petrosia sp. showed significant activity in the brineshrimp cytotoxicity assay (LD50 $=30 \mu \mathrm{g} / \mathrm{ml})$. Guided by this assay, further fractionation and purification pro- 
Table 2. Brine shrimp cytotoxicity profile of MSMs at 30 and $20^{\circ} \mathrm{C}$

\begin{tabular}{|c|c|c|c|c|}
\hline \multirow[t]{2}{*}{ MSMs } & \multirow{2}{*}{$\begin{array}{c}\text { Concentration } \\
(\%)\end{array}$} & \multicolumn{3}{|c|}{ Mortality $(\%)$} \\
\hline & & $30 \pm 2^{\circ} \mathrm{C}$ & 20 & $\pm 2{ }^{\circ} \mathrm{C}$ \\
\hline \multirow[t]{3}{*}{ D. nigra } & 0.2 & $20.0 \pm 4.14$ & & 0 \\
\hline & 0.4 & $90.0 \pm 3.94$ & & 0 \\
\hline & 0.6 & $100 \pm 0.0$ & 10.0 & \pm 1.26 \\
\hline \multirow[t]{4}{*}{ A. donnani } & 2 & $10.0 \pm 1.26$ & & 0 \\
\hline & 4 & $30.0 \pm 3.16$ & 10.2 & \pm 2.5 \\
\hline & 6 & $50.0 \pm 4.93$ & 21.2 & \pm 2.5 \\
\hline & 10 & $80.0 \pm 5.0$ & 40.0 & \pm 5.15 \\
\hline \multirow[t]{4}{*}{ C. gorgonoides } & 0.1 & $23.8 \pm 6.25$ & & 0 \\
\hline & 0.2 & $60.4 \pm 6.46$ & & 0 \\
\hline & 0.4 & $79.2 \pm 8.12$ & 20.0 & \pm 1.78 \\
\hline & 0.6 & $100 \pm 0.0$ & 80.2 & \pm 4.74 \\
\hline
\end{tabular}

Mean \pm SD. $n=10$ experiments.

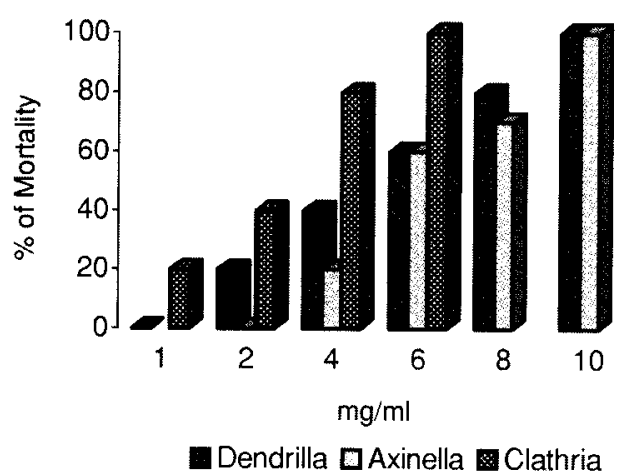

Figure 4. Larvicidal activity of MSMs.

cedures gave potent cytotoxic polyacetylenes (Kim et al., 1999). The Philippine marine sponge, Plakinastrella $\mathrm{sp}$. yielded peroxide containing metabolites and the crude methanolic extract were toxic to brineshrimp (Quershi et al., 1998). Aglestatin A isolated from Cymbastela sp. (Axinellida) was highly toxic to brineshrimp (Hong et al., 1998). The crude extracts of marine sponges, Pachastrella sp. and Jaspis sp. collected from the south sea of Korea, exhibited significant brineshrimp cytotoxicity. Guided by this bioassay, fractionation and purification gave Pectenotoxin II and Psammaplin A, which were cytotoxic to human cancer cell lines (Jung et al., 1995). Therefore, bioassay guided purification of $C$. gorgonoides and $D$. nigra may give potent cytotoxic drugs.

\section{Larvicidal effect}

Larvicidal potentials of MSMs, based on the mortality of second instar larvae are depicted in Figure 4. The
Table 3. Ichthyotoxicity profile of MSMs to Oreochromis mossambicus fingerlings

\begin{tabular}{lccc}
\hline Species & $\begin{array}{c}\text { Concentration } \\
(\%)\end{array}$ & Mortality (\%) & $\begin{array}{c}\text { Time of death } \\
(\mathrm{h})\end{array}$ \\
\hline D. nigra & 4 & 100 & 1 \\
& 2 & $60.6 \pm 5.6$ & 3 \\
C. gorgonoides & 1 & $10.0 \pm 3.34$ & 6 \\
& 4 & 100 & 2 \\
A. donnani & 2 & $70.2 \pm 4.26$ & 3 \\
& 1 & $39.8 \pm 4.0$ & 6 \\
& 4 & 100 & $50 \mathrm{Sec}$ \\
& 2 & 100 & 2 \\
& 1 & $40.8 \pm 3.96$ & 3 \\
\hline
\end{tabular}

Mean $\pm \mathrm{SD} . n=10$ experiments.

secondary metabolite of $C$. gorgonoides was found to be highly lethal to mosquito larvae. Larvicidal potential of D. nigra and A. donnani were more or less same and they produced $100 \%$ mortality at $10 \%$ level. Literature on the efficacy of sponge secondary metabolites on mosquito larvae was scanty. Methylicosadienoic acids isolated from the Caribbean sponge Cymbastela sp. (Axinellida) were contained larvicidal potential against beet army worm, Spodoptera exigua and corn rootworm Diabrotica undecimpunctata (Hong et al., 1998).

\section{Ichthyotoxicity}

Secondary metabolites produced by marine invertebrates were generally considered to play a role in the survival of host organism. They may be toxic or noxious and prevent predation, infection, and fouling or otherwise mediate ecological phenomena. This mechanism has been proved in several in vitro assays. Ichthyotoxic potential is considered as one of the mechanisms, which may indicate the feeding deterrent property of sponges to prevent predation. Although $C$. gorgonoides and $A$. donnani produced the same level of toxicity, A. donnani was considered as highly toxic and mortality was observed within $50 \mathrm{~s}$ at $4 \%$ level while it induced mortality after $2 \mathrm{~h}$, in the case of $C$. gorgonoides (Table 3). At $1 \%$ level, D. nigra exhibited $10 \%$ mortality at $6 \mathrm{~h}$ of post-exposure. The Spongia sp. reported to produce two classes of terpenoid toxin, the cytotoxic sponginolides and ichthyotoxic kurospongin (Jayatilake \& Baker, 1996). Crambines from Crambe crambe, were found to be one of the most toxic and widespread species in rocky sublittoral habitats of Mediterranean sea due to its antipredation 
Table 4. General behavioural changes observed in Oreochromis mossambicus exposed to ichthyotoxic MSMs

\begin{tabular}{ll}
\hline Stages & Behavioural changes \\
\hline State I: & a) Increased in ventilatory frequency \\
Initial signs & b) Erratic /rapid movements \\
Stage II: & a) Inclined towards one side \\
Secondary signs & b) Loss of swimming activity \\
State III: & a) Rapid surface respiration \\
Advanced signs & b) Inclined to bottom \\
& c) Start of sporadic uncontrollable \\
& swimming with non directional \\
& bursts
\end{tabular}

Table 5. Antifouling activity of secondary metabolites isolated from sponges

\begin{tabular}{cccc}
\hline Species & $\begin{array}{c}\text { Concentration } \\
\text { of extract } \\
(\mathrm{mg} / \mathrm{ml})\end{array}$ & $\begin{array}{c}\text { Fouling rate } \\
(\%)\end{array}$ & $\begin{array}{c}\text { Regaining rate } \\
(\%)\end{array}$ \\
\hline Dendrilla & 1.92 & $65 \pm 5.4$ & 100 \\
& 2.84 & $30 \pm 7.0$ & 100 \\
& 5.68 & $20 \pm 8.9$ & 100 \\
Axinella & 11.36 & 0 & 100 \\
& 19.2 & 0 & 80 \\
Clathria & 12.5 & 0 & 20 \\
& 25.0 & 0 & 0 \\
\hline
\end{tabular}

Mean \pm SD. $n=10$ experiments.

(ichthyotoxic) activity (Berlinck et al., 1992; Becerro et al., 1997).

All the MSMs exhibited more or less same sort of behavioural changes (acute toxicological reflexes) (Table 4). Initially the fishes exhibited erratic movements and then inclined towards one side. Later, they rapidly went for surface respiration followed by settling at bottom or rapid swimming activity with nondirectional bursts, which culminated in dwelling at bottom and mortality (Indap \& Pathare, 1998).

\section{Antifouling activity}

The relative potency of antifouling secondary metabolites isolated from sponges were graded as more potent to weak as $D$. nigra $>A$. donnai $>C$. gorgonoides in the decreasing order. D. nigra was more effective and safe. It completely prevented the foot adherence of common rock fouler Patella vulgata at $11.36 \mathrm{mg} / \mathrm{ml}$ (Table 5). As no earlier reports were available regarding isolation of antifouling active principles from $D$. nigra, this study forms the first report of antifouling compounds in the species. Albeit $A$. donnani prevented fouling of $P$. vulgata at $12.5 \mathrm{mg} / \mathrm{ml}$, only $20 \%$ of exposed $P$. vulgata were survived in fresh seawater. According to earlier reports, the high toxicity in A. donnani could be attributed to the presence of cytotoxins (Pettit et al., 1991; Rudi et al., 1995). In the case of $C$. gorgonoides, it was least active and prevented only $10 \%$ of foot adherence even at the higher concentration of $46.1 \mathrm{mg} / \mathrm{ml}$. Based on the present findings, it could be inferred that the extracts from the sponge $D$. nigra was new, having potent antifouling activity, which can be further used for bioassay guided purification.

If the overall bioactivity profile is considered for discussion, it could be inferred that the extract of a single species showed a wide range of bioactivity. For example, D. nigra exhibited potent antibacterial, brineshrimp cytotoxicity, larvicidal, antifouling and antipredation ichthyotoxic) activities. The actual mechanism of such a broad-spectrum of bioactivity exhibited by a single species was not known. As crude extracts only were used, they may contain more than one compound or active principles. Earlier reports on the secondary metabolites such as Puupehenone and its related metabolites isolated from Hyrtios sp. showed similar potent antibacterial, antiviral, antifungal, cytotoxic and immunomodulatory activities (Pettit et al., 1998 and references therein). Molokaiamine metabolite from Aplysinella sp. showed antiviral, antifouling and cytotoxic activities (Fu \& Schmitz, 1999 and references therein). Manzamine-type alkaloids isolated from the Philippine marine sponge Xestospongia ashmorica showed insecticidal, antibacterial and cytotoxicity activities (Edrada, et al., 1996). Cacospongionolide, B a new sesterpene, isolated from Fasciospongia covernosa showed antimicrobial activity, brineshrimp cytotoxicity and ichythyotoxicity (de-Rosa et al., 1995). Contrary to the earlier reports of Axinella, A. donnani showed lower activity in the antimicrobial and brineshrimp cytotoxicity assays (Uriz et al., 1992; Barrow \& Capon, 1993; Bandaranayake, 1994; Rudi et al., 1997).

In accordance with the present study, crude extract of Clathria sp. showed significant feeding deterrent, cytotoxic and haemolytic activities (Kamiya et al., 1990; Wright et al., 1997). The feeding deterrent activity was reported as a chemical defense in Antartic sponge Dendrilla membrosa (Baker et al., 1995). The 


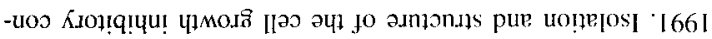

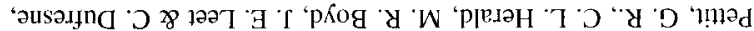
$8 \mathrm{IZ}-\mathrm{tIZ}: \mathrm{z} 2$ slonpord [p.minen jo

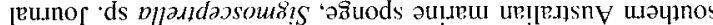

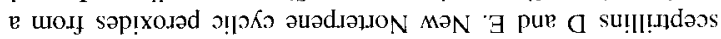

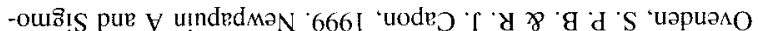

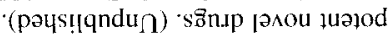

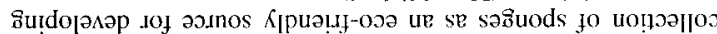

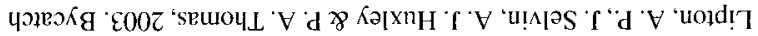

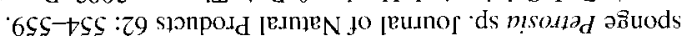

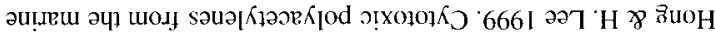

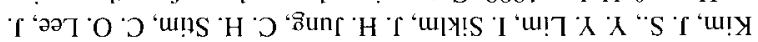

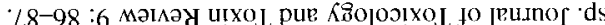

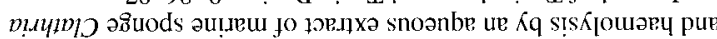

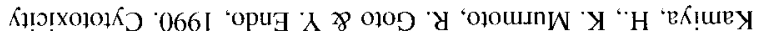

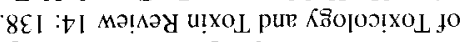

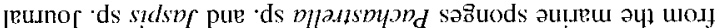
spunoduro an!

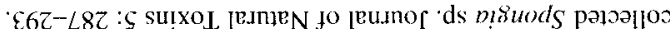

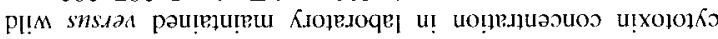

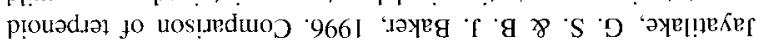
$01-\varepsilon: \varepsilon$ К

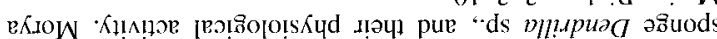

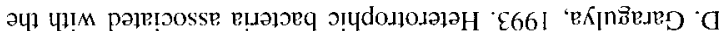

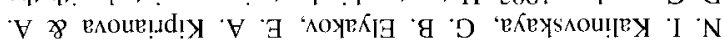

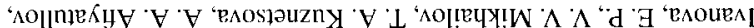
t大t

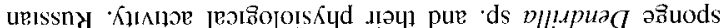

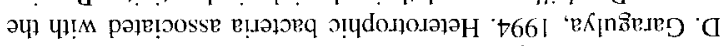

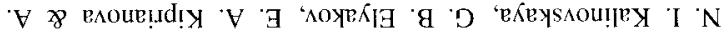

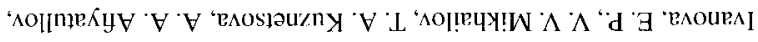

't

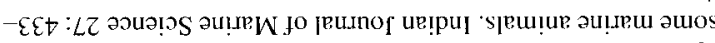

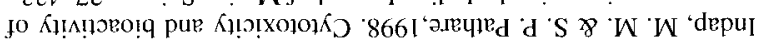
$\cdot 191-8 \mathrm{SI}: 19$ sjonpo.I [e.mpen jo [eumor 'u!p?

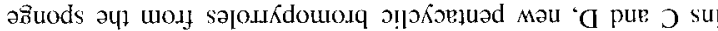

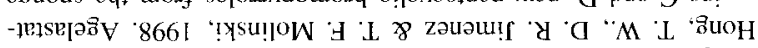

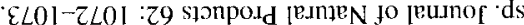

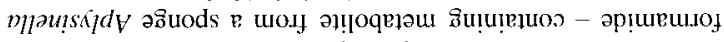

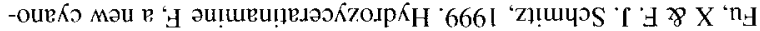
$8 Z S I-\angle Z S I: \varepsilon 9$

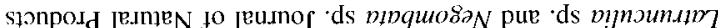

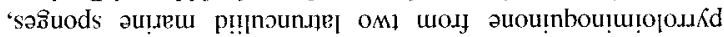

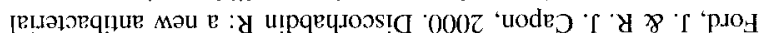

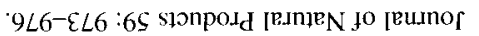

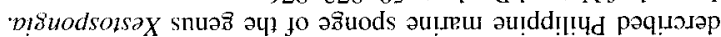

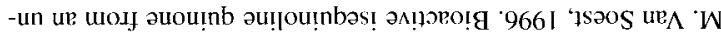

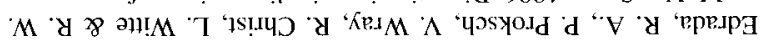

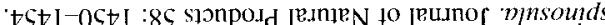
p!n

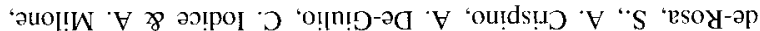
$\varsigma[-2 Z 1: 19$ słonpord [e.Jmen Io jeunof :Andstp splag

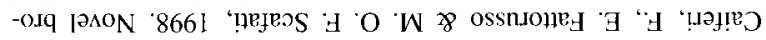

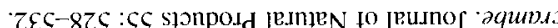

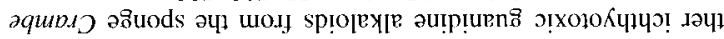

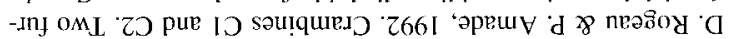
"o!poly ' $68-L L$

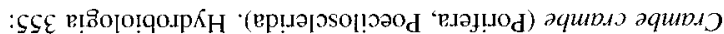

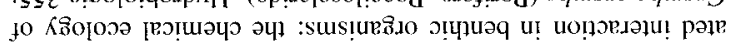

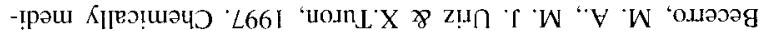

$0 \Omega-\varepsilon 7 z: I$ s.อna

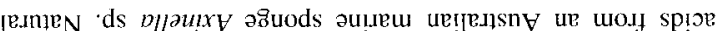

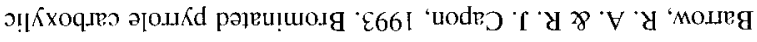
'IZ:81 SWIV

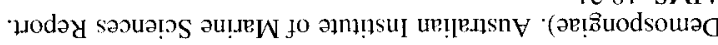

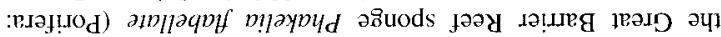

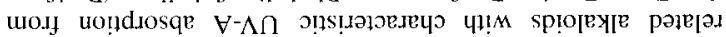

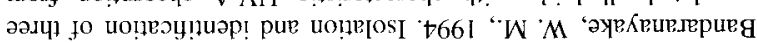

$29+1$

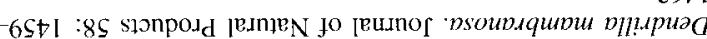

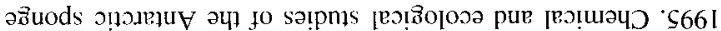

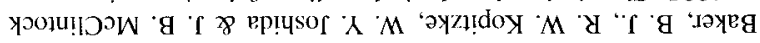
$688 \subseteq \mathrm{I}-288 \mathrm{SI}: 99 \mathrm{Z}$

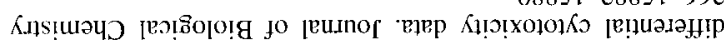

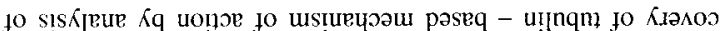

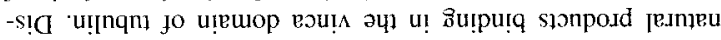

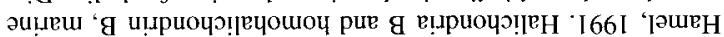
当 8 m th I :YIOX Man 'SSOId

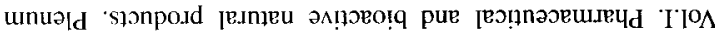
К $\mathrm{s}$ olouy

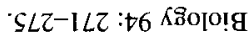
әแ!़ा '

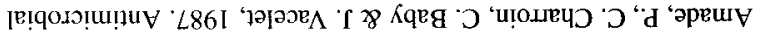

รววนวдวృа

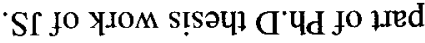

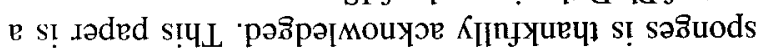

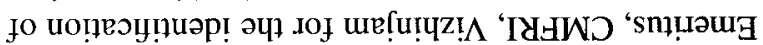

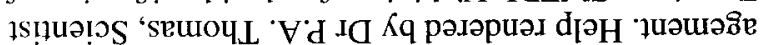

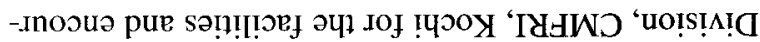

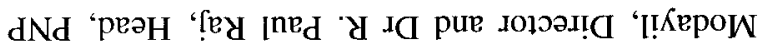

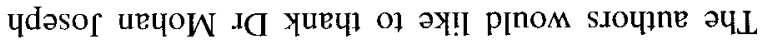

sұนวนวริpə[MоuYว

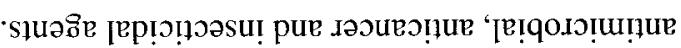

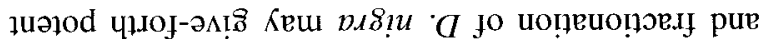

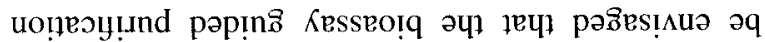

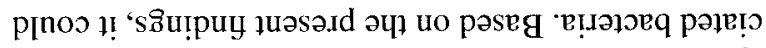

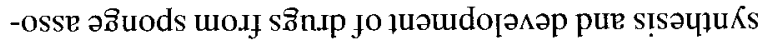

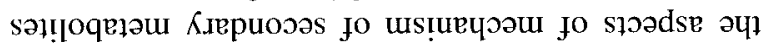

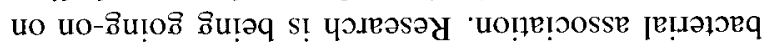

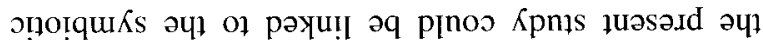

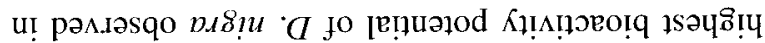

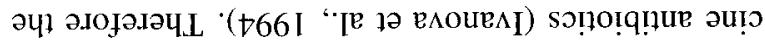

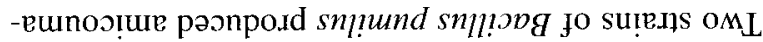

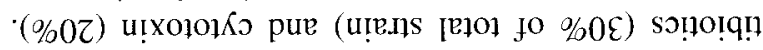

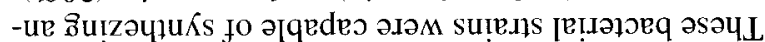

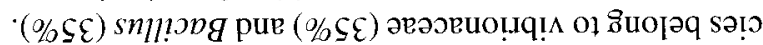

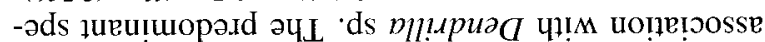

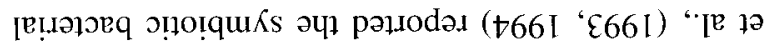

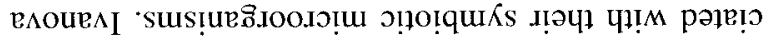

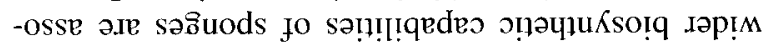


stitutents from the western Pacific marine sponge Axinella $\mathrm{sp}$ Arizona State University Reports: p 4.

Pettit, G. R., Z. A. Cichacz, R. Tan, M. S. Hoard, N. Melodyn \& R. R. Pettit, 1998. Antineoplastic agents. 386. Isolation of Sesterstatins 1-3 from the marine sponge Hyrtios erecta. Journal of Natural Products 61: 13-16.

Quershi, A., J. Salva, M. K. Harper \& J. D. Faulkner, 1998. New cyclic peroxides from the Philippine sponge Plakinastrella $\mathrm{sp}$. Journal of Natural Products 61: 1539-1542.

Rudi, A., M. Aknin, E. M. Gaydou \& Y. Kashman, 1997. Sodwanones $\mathrm{K}, \mathrm{L}$ and $\mathrm{M}$ : New triterpenes from the marine sponge Axinella weltneri. Journal of Natural Products 60:700-703.

Rudi, A., I. Goldberg, Z. Stein, Y. Kashman, Y. Benayahu, M Schleyer \& M. D. Garcia-Gravalos, 1995. Sodwanones G., H. and $\mathbf{I}$., new cytotoxic triterpenes from a marine sponge. Journal of Natural Products 58: 1702-1712.

Selvin, J., 2002. Shrimp disease management using secondary metabolites isolated from marine organisms. Ph.D thesis submitted to M.S. University, Tirunelveli, India: 204 pp.

Selvin, J. \& A. P. Lipton, 2002. Development of a rapid 'molluse foot adherence bioassay' for detecting potent antifouling bioactive compounds. Current Science. 83: 735-737.

Soniya, J., 2003. Exploration of sponge associated Actinomycetes for the development of potent novel antibacterial agents. M.Sc dissertation submitted to M.S. University, Tirunelveli, India: pp 102.
The HiMedia Manual for microbiology laboratory practice. 1998. HiMedia Laboratories Pvt. Limited, Mumbai: 524 pp.

United States Pharmacopoeia / National Formulary (USP 23 / NF 18), 1995. US Pharmacopoeia Convention, Inc., Rockville, Md.

Urban, S., M. S. Butler \& R. J. Capon, 1994. Lamellarins O and $P$ : new aromatic metabolites from the Australian marine sponge Dendrilla cactos. Australian Journal of Chemistry 49: 1919-1924.

Uriz, M. J., D. Martin \& D. Rossell, 1992. Relationships of biological and taxonomic characteristics to chemically mediated bioactivity in Mediterranean littoral sponges. Marine Biology 113: 287-297.

Venkateswarlu, Y. \& M. A. F. Biabani, 1995. Phycopsisenone. A new phenolic secondary metabolic from the sponge Phycopsis sp. Journal of Natural Products 58: 269-270.

WHO, 1981. Instructions for determining the susceptibility or resistance of mosquito larvae to insecticides. WHO/VBC/81-807. rm 100 .

Wright, J. T., K. Bekendorff \& A. R. Davis, 1997. Habitat associated difference in temperate sponge assemblages: the importance of chemical defense. Journal of Experimental Marine Biology and Ecology. 213: 199-213.

Wardlaw, A. C, 1985. Practical Statistics for Experimental Biologists. John Wiley and Sons, Chichester. 